\section{Doreen Liberto-Blanck}

AICP, Lecturer

City and Regional Planning, Cal Poly

Community Development Director, King City CA
Making All The Difference-Using Higher Education In Planning King City's Future

One of the fundamental roles of universities is to contribute to community development and social equity. LibertoBlanck, a lecturer at Cal Poly's City and Regional Planning Department and King City community development director, discusses her job, the urgent needs that the city is facing, and the importance of the CRP department community-outreach pedagogy and of the contributions represented by ongoing student work.

When first approached by Michael Jencks, the then-City Attorney for King City, to help resolve some complex land use and environmental issues in King City, I did not anticipate my company would eventually become responsible for the entire community development department. Nor, did I realize the critical part Cal Poly's City and Regional Planning Department would play in the city's future. At the time, my company had other opportunities: a land use mediation in Northern California and a large mixed use specific plan in a well-established city in Southern California. But those assignments would have been by rote. Realizing King City was the real challenge, Robert Frost's poem, The Road Not Taken, flashed in my head.

King City is located in southern Monterey County, along Highway 101, and approximately 70 miles north of Cal Poly. It was incorporated in 1911 . The City provides a great example of New Urbanism because it was built on a grid pattern, and has small walkable streets lined with trees. There is a faint outline of an older "downtown" area along a portion of Broadway Street that is in need of rehabilitation. Recognizing the historic strengths of the community, one resident said, "We have some good bones in this town, we just need calcium to make them stronger!"

While the 2000 Census estimated the population to be approximately 11,000 people, due to overcrowding living conditions due primarily to lack of farmworker housing, it is safe to say that thousands more can be added to the census count. ${ }^{1}$ Of the 11,000 people, 80 percent identified themselves as Hispanic or Latino. The City municipal boundary contains

1 According to the City's 2003 Certified Housing Element, a home is considered to be overcrowded when there is more than one person per room in the house. Data from the 1990 census indicated that 715 households were overcrowded in King City, including 552 renter households and 163 owner households. Based on a straightline projection, this is equivalent to 618 renter households and 182 owner households in 1995. The average household size in King City increased from 3.34 persons in 1990 to 3.8 in 1995. Therefore, household overcrowding in King City remains a housing concern. approximately 1,449 acres with an additional 6,133 acres within its General Plan Planning Area.

The Santa Lucia Mountains and the Los Padres National Forest are west of King City and provide a door to the Pacific Ocean. The Pinnacles National Monument, where an ancient volcano and massive monoliths and sheer walled canyons can be explored, is located to the east. The Salinas River runs through the City, and several local creeks help replenish the groundwater aquifers.

The community has many assets that may not be apparent when traveling along Highway 101. The George L. Mee Memorial Hospital provides primary care, with a heliport, and is one of the City's major employers. King City owns and operates the Mesa del Rey Airport, which includes a 4,485 foot long paved runway. Additionally, there is a Greyhound bus stop, and the Union Pacific Railroad's main coastal rail line runs along First Street. San Lorenzo Park, which includes the Monterey County Agricultural and Rural Life Museum and 90 campsites, is located along the banks of the Salinas River. The King City Fairgrounds, a city owned golf course and Hartnell College's Education Center are other community strengths.

The agricultural industry provides the most jobs, with education and social services following. King City is considered the south end of the Salinas Valley, which is known as the "Salad Bowl of the Nation.”The City is surrounded by prime agricultural land due to the high quality soils deposited over time by the Salinas River. However, King City, like the rest of Monterey County, faces development pressure due to Silicon Valley, Monterey and Salinas area workers willing to commute long distances in exchange for the opportunity to purchase a home.

The growth pressure on King City is similar to what I experienced in Southern California when hired as City Planner for the newly incorporated city of Moreno Valley located in Riverside County. Young families working in Los 
Angeles and Orange County were anxious to own a home in which to raise children but could not afford anything close to their jobs. The growth pressure on Moreno Valley was mounting and large developments including three separate 10,000-acre specific plans, were waiting in line for approval. However, Moreno Valley had one critical piece of the puzzle King City lacks: a robust budget. While Moreno Valley could afford to contract with high priced consulting firms and pay the Urban Land Institute (ULI) to prepare a longrange plan, King City is forced to live frugally in difficult economic times.

Due to budget constraints, King City was forced to reduce the staff workweek to 36 hours and close City Hall on Friday. The City was forced to endure severe staff reductions and privatized a number of City services to save money. The Planning and Building Department was divided into two separate departments. The City contracts with Monterey County to provide building inspection. Earth Design, Inc. provides staff for the Community Development Department, and Boyle Engineering and Hanna and Brunetti Engineering provide City Engineering Services.

The City's development application review fee schedule was revised based on time and materials rather than a flat application fee. Developers submitting large projects are required to enter into a Memorandum of Understanding (MOU) that requires a substantial upfront deposit to cover all costs associated with processing applications. The deposit is placed in a separate trust account and replenished when it goes below a certain amount. A number of State grant proposals have been accepted and are providing additional funds for a number of projects. For example, the City recently received

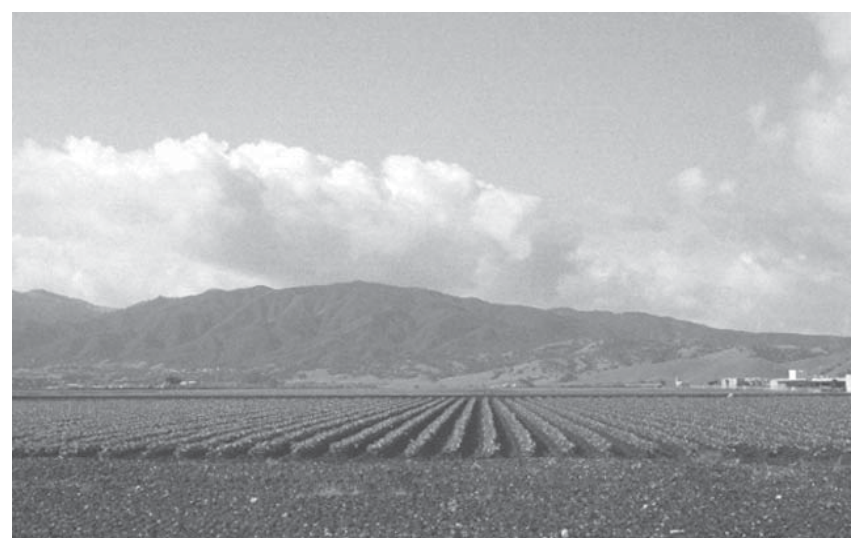

Figure 1: An agricultural field in King City, which is located in the south end of the Salinas Valley, known as the "Salad Bowl of the Nation". a grant to prepare a geographical information system (GIS) base map with all infrastructure locations. Although this may sound fundamental in most jurisdictions, it is a major advancement in King City.

Police and fire services are in severe need of funding. The police department operates with a minimum paid staff, and the fire department is all volunteer. To help generate more revenue for public safety, in November 2005, King City held a special election to raise the utility user tax rate on telephone, electricity, water, gas, and cable television services to the statewide average of six percent subject to annual review by a Citizen Advisory Committee. It is interesting to note that only 910 people voted in the election and the proposed tax lost.

The City's planning documents need updating. For example, the zoning ordinance was adopted in 1973. But clearly the City does not have the financial resources to comprehensively update all planning documents at one time. Small and medium sized cities can no longer fund the large planning programs of a decade ago and have to find creative approaches to fund planning programs. Cities provide services such as fire and police services, water, sewer, parks and recreation, public works and planning programs. These services are paid for from local taxes, fees and user charges, state and federal assistance and other resources.

However, over the decades, the federal and state governments have substantially reduced the amount of aid provided to local government. In tough economic times, usually the first programs to be cut are planning programs. In order for King City to prepare for future development, joint participation and cooperation by higher educational institutions, public sector,

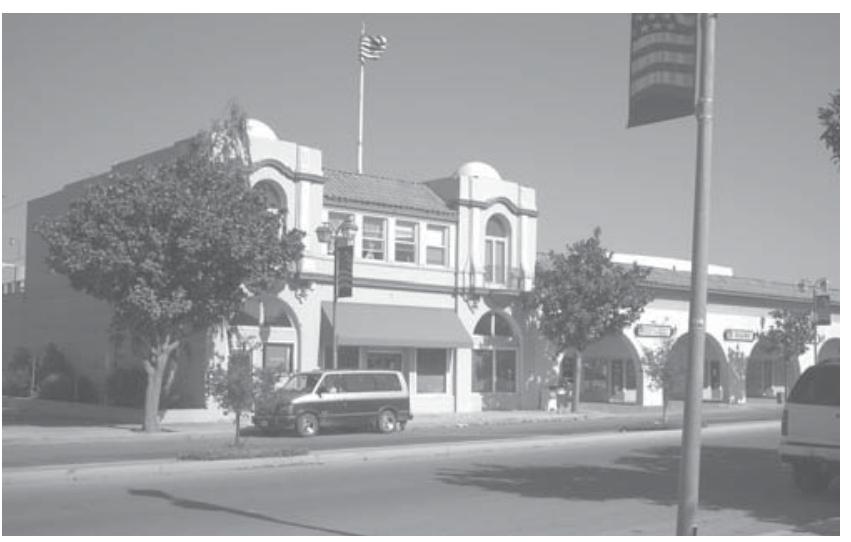

Figure 2: Corner building in the downtown. Staff will recommend the downtown be referred to as an Aldea (or Village). 
private enterprise and non-profit organizations are critical. Ann Marie Gallant, the City Manager and I decided one key in helping the City's future is to update the community development documents and to tap into the talents of the faculty and students of Cal Poly's City and Regional Planning Department, as is discussed in more detail below.

King City has been completely unprepared for the onslaught of development encroaching from the Silicon ValleyMonterey-Salinas area. In early 2000, the City processed a Sphere of Influence (SOI) amendment of 565 acres which would allow 800 new dwelling units. However, the Monterey County Local Agency Formation Commission (LAFCo) decided that only 210 acres could be annexed and the remaining 355 acres should be placed in an agricultural conservation easement. This required the 800 units be built on 210 acres rather than 565 acres, making the project denser. The agricultural conservation easement does make a buffer zone at the City's edge. CreekBridge Homes (of Salinas) and Woodman Development, Co. and Urban Community Partners (of Monterey) developed adjacent specific plans for that area, each proposing 400 housing units.

In July 2004, CreekBridge Homes's Arboleda Specific Plan was approved and included soccer, baseball and linear parks, tot lots, and a new middle school. Pedestrian sidewalks and smaller streets meander along the community's various housing types and sizes. In August 2005, the adjacent Mills Ranch Specific Plan by Woodman Development, Co. and Urban Community Partners was approved with the intent to develop a neighborhood based upon traditional neighborhood design planning principles.

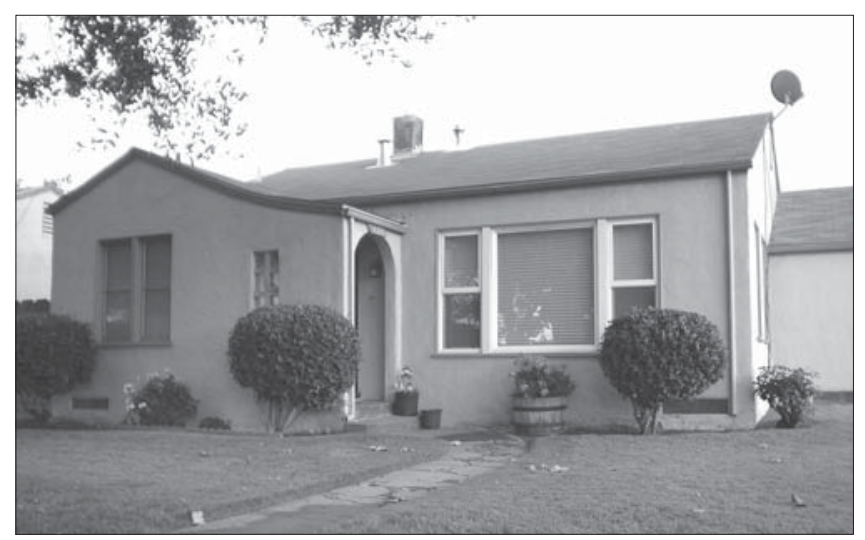

Figure 3: Example of the housing type that gives King City a small town flavor.
The issuance of the building permits for the Arboleda and Mill Ranch Specific Plans is helping the City's finances; however, it is only a short-term income. There are several property owners within the unincorporated area that have approached the city requesting annexation within the next 20-years. Before this can occur, the Monterey County LAFCo must give approval, and substantial planning, environmental and infrastructure work must be completed. Many property owners are approaching King City about annexation because Monterey County has gone through a tumultuous general plan update over the last six years that centers on how to address rural growth. A general plan County growth control initiative recently qualified for the June 2006 ballot. The initiative would direct growth toward the cities in the Monterey County. Therefore, it is important for King City to plan for substantial growth for the next 20-years.

In anticipation of the continued growth pressure, King City leaders understand the need to update their planning and regulatory documents to protect their city's future. The City has begun preparing a Citywide SOI amendment. Five properties within the unincorporated area will be included within the SOI amendment. An Environmental Impact Report (EIR) and Capital Improvement Plan (CIP) will accompany the SOI amendment to LAFCo for a determination on the City's 20-year growth boundary. The CIP will consider the following issues:

- Traffic and Circulation Master Plan.

- Wastewater Master Plan.

- Wastewater Collection System Master Plan.

- Storm Drain System Master Plan.

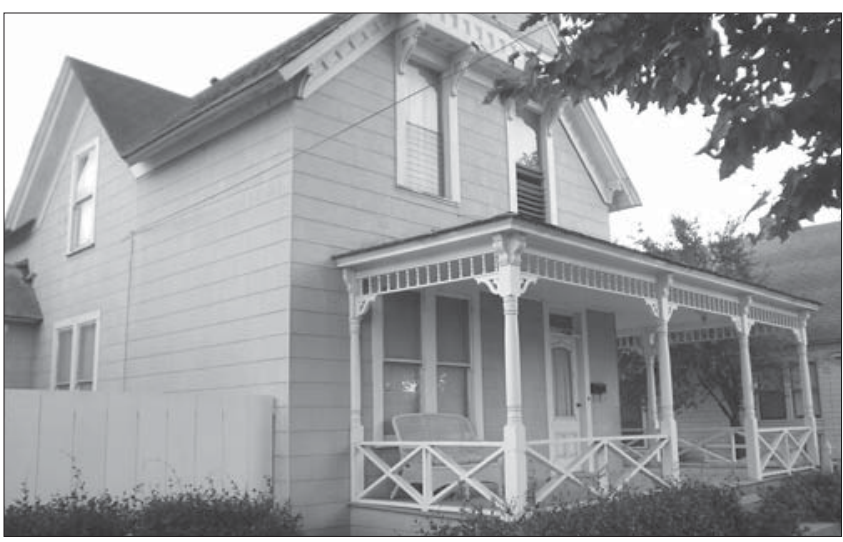

Figure 4: Another example of Main Street America housing stock in King City. 
- Park Facility Master Plan.

- Police and Fire Safety Facilities Master Plan.

Each master plan will include an analysis of existing City conditions; background conditions which include recently approved development projects; cumulative project scenarios; a summary of relevant plans; funding infrastructure improvements; and funding and reimbursement for the master plan preparation costs. The master plans will be combined into a CIP, including a budget and impact fee schedule. The SOI amendment and CIP will be presented to LAFCo to demonstrate that the City can accommodate the build out of the proposed area within the next 20-years. If LAFCo approves the SOI amendment, the City and LAFCo can consider applicant sponsored annexation, prezoning and specific plan requests.

Concurrent with processing the Citywide SOI amendment, the 1973 zoning ordinance and other development regulations are being updated. The City will amend the corresponding general plan goals and policies. As mentioned above, Cal Poly's City and Regional Planning Department is playing an important role in shaping the City's future. In the fall of 2005, and under the auspices of assistant professor Cornelius Nuworsoo and adjunct professor Ken Topping, the City and Regional Planning Department students in the graduate Community Planning Laboratory (CRP 552) produced a Background Report based on public outreach and substantial community research. ${ }^{2}$

The students contacted community members, including members of the Spanish speaking community, to determine community strengths and desires. Recently, the Background Report was produced summarizing their findings. The Background Report also includes recommended goals and objectives for the City's future growth. The students in CRP 552 will final their project in winter quarter in the Regional Planning and Analysis class (CRP 554). In mid-March, a joint City Council and Planning Commission meeting will be conducted requesting community input on the final document produced by the class. As the City updates the general plan and prepares the development code, the final goals and objectives presented by the students will be given strong consideration by staff and policy makers.

A component of the general plan update and development code preparation will be to define a "downtown" area.

\footnotetext{
${ }^{2}$ Note from FOCUS: see the next article in this Student Work Section by Nurwusoo and Topping.
}

As mentioned above, an older area engulfing a portion of Broadway near First Street will be recommended for future renovation and identified as an "Aldea.” The Aldea, or village, will include mixed uses, a pedestrian friendly streetscape, renovated buildings, and mixed cultural activities. The Aldea will eventually transition into a 90-acre Transit Oriented Development (TOD) specific plan submitted by the property owner, which is located across First Street. It is anticipated that Union Pacific Railroad will eventually have a stop in this area of King City.

The City is also considering what to do with the mid-1900 vintage motels located along Broadway Street and First Street that are low-income residents. The lack of low-cost housing and migrant farm worker housing is an issue the City will address through a combination of private funds, public grants and non-profit organizations. King City is fortunate to have a State certified Housing Element, so there are a number of available grants available to address this growing problem.

The City and Regional Planning Department may be helping shape the City's future in other ways for years to come, as the City Manager has provided a long wish list of student and class projects for consideration. King City has a long voyage and many obstacles to overcome but with strong leadership and a collaborative approach utilizing the talents made available by higher education, private industry, public entities and non-profits. . . well, as Robert Frost concludes,

Somewhere ages and ages hences:

Two roads diverged in a wood, and I-

I took the one less traveled by, And that has made all the difference. 